\section{Maximizing the Mining Exploitation Efficiency of a Quarry: A Case Study}

Rudarsko-geološko-naftni zbornik

(The Mining-Geology-Petroleum Engineering Bulletin) UDC: 622.2

DOI: 10.17794/rgn.2021.5.3

Preliminary communication

\author{
Arezou Rasti'; Nader Ebrahimi²; Morteza Tabaei²; Hamid Ranjkesh Adarmanabadi ${ }^{1}$ \\ ${ }^{1}$ New Mexico Institute of Mining and Technology, Department of Mineral Engineering, Socorro, New Mexico, United States \\ ${ }^{2}$ Isfahan University of Technology, Department of Mining Engineering, Isfahan, Iran
}

\begin{abstract}
Nowadays, the dimension stone industry performs a crucial role in the world economy. Accordingly, dimension stone quarries' importance grows due to their different applications in various construction, building, and decorative industries. Some issues threaten this industry and provide a financial risk that should be taken into account to make the smallest possible risk for investment. The presence of discontinuities in the rock mass has a key function as far as it concerns the overall quality of in situ rock blocks. It impacts the feasibility of dimension stone quarries and overall mine exploitation efficiency. Therefore, it is recommended to survey discontinuities and rock blocks and estimate the average geometry of a rock block, including the shape and size, before mining the benches to maximize mining exploitation efficiency and minimize waste ore production. This investigation aims to survey the discontinuities of the limestone quarry mine located in Josheghan, Iran, to determine and calculate rock blocks' suitable geometry and an extraction's direction for active mine benches. For this purpose, the scanline method was applied to survey discontinuities in seven active benches. $3 \mathrm{DEC}$ software was used to indicate discontinuities and model the rock blocks for all active benches. It was concluded that the benches' cutting line make a 13.14 degree with the discontinuities main's direction. The result of this study proved that by changing the direction of mining and extraction for active mine benches, the unnecessary waste production would decrease. The production rate with the recommended extraction direction will increase by about $1.13 \%$ compared to the current extraction direction, which makes 13.14 degrees with the discontinuities main's direction. Currently, bench seven recorded the minimum production rate, which is 97.60 ; by applying the new extraction's direction, it is predicted that this bench will achieve a 99.83 production rate. Consequently, it is concluded by improving the production rate, exploitation efficiency would increase considerably.
\end{abstract}

Keywords:

dimension stone; financial risk; discontinuity network; exploitation efficiency; rock block's geometry

\section{Introduction}

Dimension stone can be defined as various natural stones used for structural or decorative applications. They can be used in construction and building, and monumental sectors. Different rock types are used as dimensional stones, such as granite, gneiss, gabbro, diabase, marble, sandstone, limestone, slate, and soapstone. The appearance of natural stone, the possibility of producing rectangular blocks and market demand represent the success in the dimension stone industry (Niini, 1986; Luodes et al., 2000; Ashmole and Motloung, 2008). In the industrial division, natural stones which are used as a decorative material for covering, and a structural purpose called decorative or ornamental stones (Careddu et al., 2019). The dimension stone industry is growing.

Corresponding author: Arezou Rasti

arezou.rasti@student.nmt.edu
It is expected that the world quarry gross product will reach three hundred-ten million tons in 2025, and an amount of about one hundred-sixty million tons of this value is waste material. Therefore, it is essential to practice and apply the appropriate guidelines in the dimension stone industry to be able to contribute efficiently to economic development (Careddu et al., 2019). For this purpose, two main steps should be followed, including conducting the precise and comprehensive geological and geotechnical investigation of the mine and applying the appropriate quarrying method defined in the stone processing stage to minimize the waste production (Careddu, 2019; Careddu et al., 2014). Minimizing the waste stone produced during exploitation and processing is more preferable than stone recycling in terms of environmental and economic impacts (Elkarmoty et al., 2020).

Various parameters and factors affect the profitability of the dimension stone quarry mine and further develop- 
ment, such as block size. It is essential to optimize the block size and produce high-quality raw materials since it decreases the unnecessary waste and overburden productions (Mosch et al., 2011; Rzyczniak et al., 2021). The combination of intact rock and discontinuities network is known as a dimension stone deposit (Yarahmadi et al., 2018; Freire-Lista and Fort, 2017). Discontinuities are critical parameters that should be assessed during exploration and in the stone processing stage. It also illustrates the exploitability of commercial-size ornamental stone blocks from quarries (Elkarmoty et al., 2020; Carvalho et al., 2008; Levytskyi et al., 2018). Discontinuities are the leading causes of waste products in the quarrying industry (Elkarmoty et al., 2020). Waste materials are a considerable amount of the dimension stone quarries' products (Cavallo, 2018). Therefore, determining the discontinuity condition, especially the joint set orientation, and examining the ratio between discontinuity intensity and excavation dimensions has the highest priority in the dimensional stone industry (Hamdi Deliormanli et al., 2014). Any mechanical break and interruption in the properties of the rock mass are defined as a discontinuity (Priest and Hudson, 1976). Faults, bedding planes, joints, and cleavage are the main types of discontinuities. To describe discontinuities' characteristics, ten parameters should be defined, including orientation, spacing, persistence, roughness, wall strength, aperture, filling, seepage, number of sets, and block size (Zhang et al., 2006; T. Li et al., 2021).

There are different methods to measure the characterization of rock mass discontinuities. These methods are classified into two main groups: direct contact measurements with a geological compass, clinometer, and measuring tape and non-contact measuring techniques such as photogrammetry and light detection and ranging (LiDAR) (X. Li et al., 2019; Franklin et al., 1988). The ten parameters describe discontinuities and rock mass, including orientation, spacing, persistence, roughness, wall strength, aperture, filling, seepage, number of sets, and block size (Barton, 1978). Two different techniques are presented to survey discontinuities and rock blocks classified into index and modelling methods. Each one has several advantages and disadvantages that can be followed based on the project goal and equipment availability. Scanline survey, image processing, GPR technique, and window mapping are recommended methods to survey discontinuities. Discontinuities survey method selection depends on various factors, including the projects' purpose, rock mass accessibility, and discontinuities condition in terms of their density and orientation. One or more than one method will be applied to survey the discontinuities by considering all internal and external parameters (Yarahmadi et al., 2015). Scanline and window mapping techniques are conventional methods that systematically sample the discontinuity parameters. In the scanline mapping, important parameters of all discontinuities which intersect a straight tape are measured. In window mapping, discontinuities' parameters contained within the window are recorded (Sturzenegger, 2010).

The distinct element method is a dominant technique that was introduced in 1971 by Cundall. This technique has several applications, such as modelling blocky rock masses that contained persistent discontinuities. Discontinuities are considered distinct boundary interactions between these blocks (Cundall, 1971; Wang et al., 2012). The 3D Distinct Element Code (3DEC) is an appropriate technique to model wave propagation in the complex 3D jointed rock mass. In 2012, the 3DEC capability to model wave propagation across rock discontinuities was verified. Deng et al. analysed the effects of various discontinuity parameters on wave propagation (Deng et al., 2012). Additionally, 3DEC with various methods has recorded several applications. In 2020, the deformation mechanism and stability of the arch crown in large-scale underground caverns during excavation was conducted by using $3 \mathrm{Dec}$ and MS monitoring (Hu et al., 2020). This investigation aims to control and assess the limestone quarry mine's block size and orientation in Josheghan, Iran. A three-dimensional numerical model was built using the 3DEC software package to assign a network of discontinuities and simulate the rock block.

\section{Case study}

The Josheghan Quarry Mine is located in Josheghan Ghali town, $110 \mathrm{~km}$ northwest of Isfahan Province. Isfahan is located in the centre of Iran. The location of the quarry mine is presented in Figure 1. Several quarry mines are located in this area. For this investigation, an active limestone marble quarry named Sepid Sang was selected as a case study. This quarry was formed during the Oligocene-Miocene periods. The main product of this mine is limestone. Regarding rock mass properties, it is presented that the rock mass has a recorded $50-80 \mathrm{MPa}$ compressive strength. Some stochastic discontinuities were observed in the rock mass due to tectonics activities.

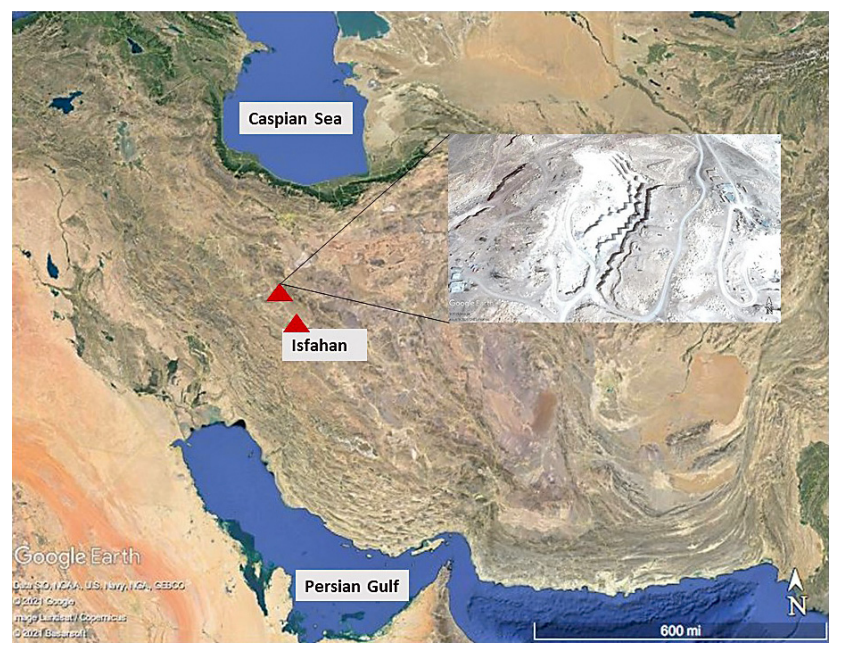

Figure 1: Josheghan Quarry Mine location (source: Google Earth) 


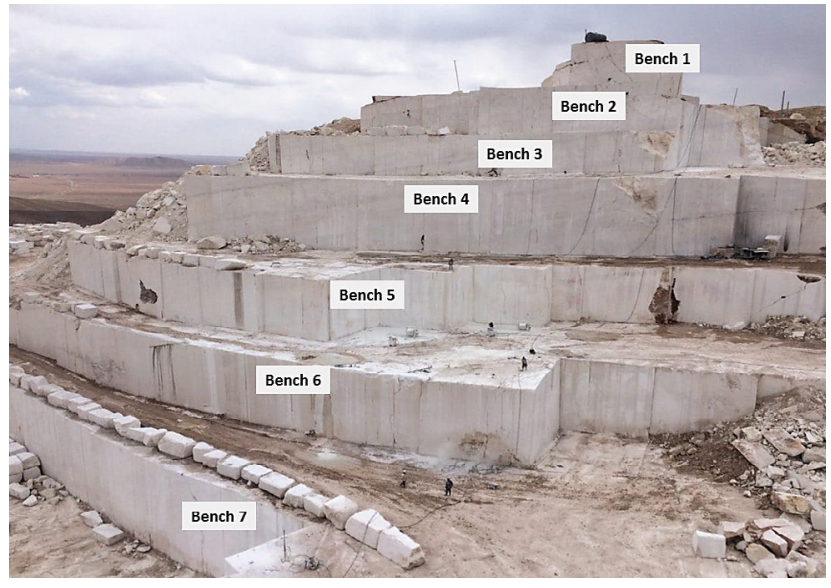

Figure 2: Josheghan Quarry Mine

Josheghan Quarry Mine mainly contained uniformly white limestone. The mine has seven active benches (see Figure 2). The height of the benches varies from $6.5 \mathrm{~m}$ to $13.3 \mathrm{~m}$ with lengths ranging from $58 \mathrm{~m}$ to $94 \mathrm{~m}$. The daily production is 500 tons, and the diamond wire cutting method is applied to extract blocks. The diamond wire technique is an essential instrument that has been extensively applied in stone quarries (Ataei et al., 2011; Khoshouei et al., 2020, Yarahmadi et al., 2015).

\section{Methodology}

\subsection{Discontinuity survey}

The result of the field investigation proved that there are various discontinuities in the rock masses. Besides, quarry stone management is exceptionally dependent on

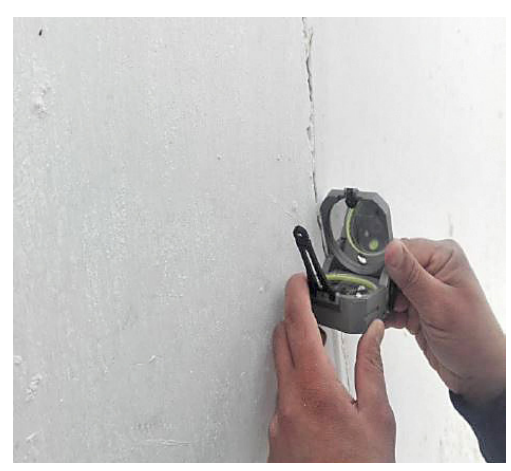

Figure 3: Discontinuity survey the discontinuity pattern. Therefore, as discussed, the first step to determine the rock block's geometry is surveying the discontinuities (Sousa, 2010). In this investigation, significant lengths of wall exposure were available; therefore, the scanline method was recommended to provide the field's geotechnical information (Wines and Lilly, 2002). In this study the properties of all discontinuities intersecting the scanline for five benches are collected. Strike and dip of discontinuities were measured using a compass to indicate the two-dimensional maps (see Figure 3).

The joint spacing is the first indication of block size (Palmstrom and Broch, 2006). The effect of discontinuity patterns on the mine bench stability with respect to the direction of mine excavation is influenced by the joint set orientation, the spacing of the relevant discontinuities, and the joints' aperture. The stereographic projection software Dips was used to present the discontinuities orientation. After the discontinuity survey, the pole density contour map for each bench was obtained (see Figure 4).

Table 1 indicates the results of a discontinuity survey for each active bench. The discontinuity survey results proved that from bench 1 to bench 5 , discontinuity separation (aperture) decreases, and discontinuity spacing increases due to the high-stress concentrations. Therefore, the exploitation efficiency of the quarry can increase by increasing the depth since the appropriate blocks with acceptable geometry can be quarried. Since it was impossible to survey the discontinuities in bench 6 and 7 due to the hard accessibility, it was assumed that the discontinuities properties for bench 6 and 7 are similar to bench 5 .

\subsection{Discontinuity modelling}

It is recommended that the experiment be simulated using numerical methods. The discontinuity network obtained from discontinuity surveys is utilized as an input parameter to determine the blocks' geometry for each bench. There are three different techniques to assign the rock block, including index evaluation, image-based measurement, and modelling methods (Yarahmadi et al., 2015). In this investigation, the discontinuity modelling method was conducted to assign the rock block using the discontinuity network, and 3DEC was used to model the rock mass components (Itasca Consulting

Table 1: Discontinuity survey result

\begin{tabular}{|l|c|c|c|c|c|}
\hline Bench & Number of joints & $\begin{array}{c}\text { Joint set Dip } \\
\left({ }^{\circ}\right)\end{array}$ & $\begin{array}{c}\text { Joint set Dip Direction } \\
\left({ }^{\circ}\right)\end{array}$ & $\begin{array}{c}\text { Spacing of discontinuities } \\
(\mathbf{m})\end{array}$ & $\begin{array}{c}\text { Separation (aperture) } \\
(\mathbf{c m})\end{array}$ \\
\hline 1 & 14 & 80.07 & 13.5 & 2.06 & 1.28 \\
\hline 2 & 22 & 81.27 & 13.5 & 2.30 & 0.90 \\
\hline 3 & 19 & 80.95 & 13.63 & 2.45 & 0.66 \\
\hline 4 & 17 & 79.60 & 13.35 & 2.70 & 0.54 \\
\hline 5 & 15 & 79.90 & 13.2 & 2.98 & 0.65 \\
\hline
\end{tabular}



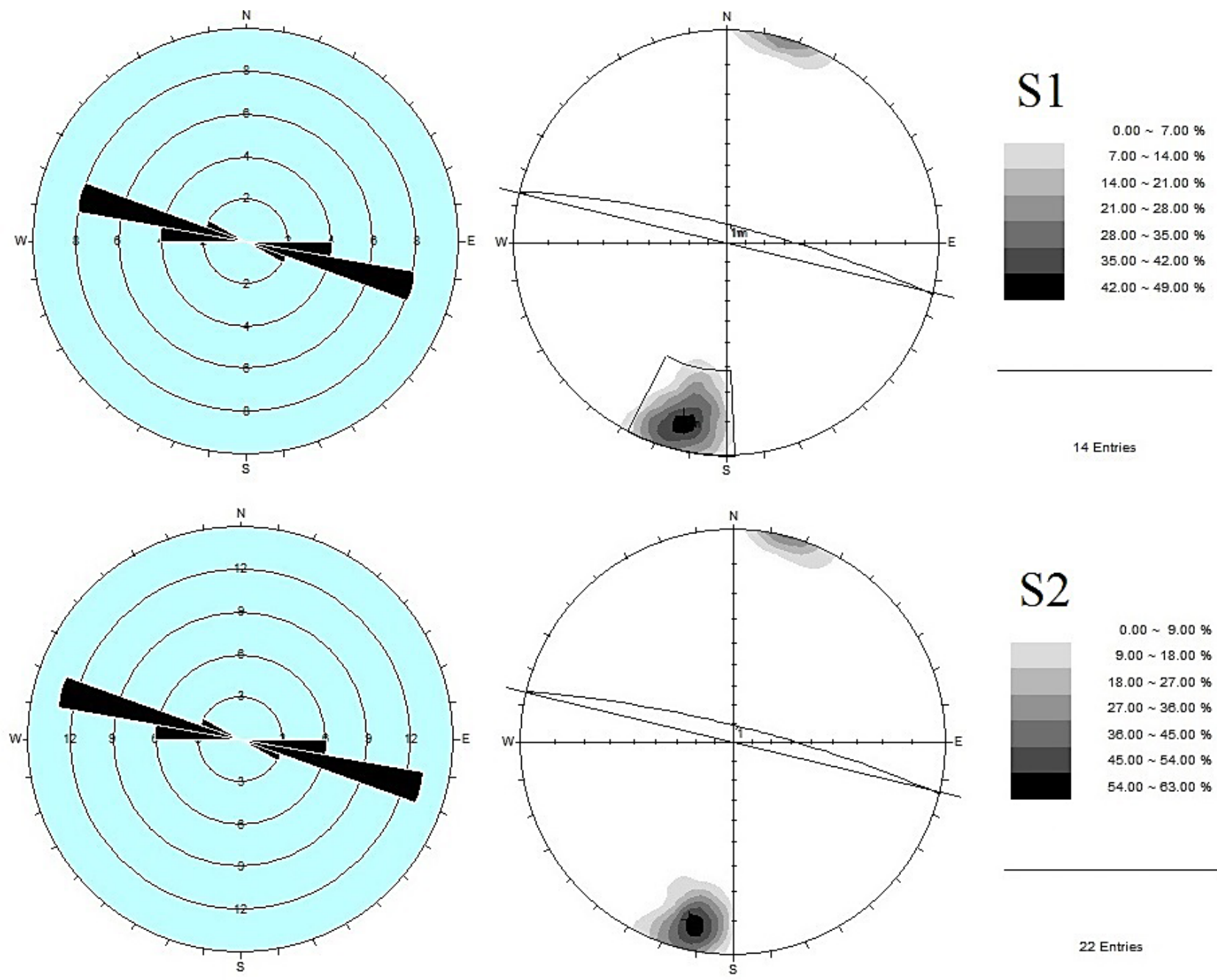

S2

14 Entries
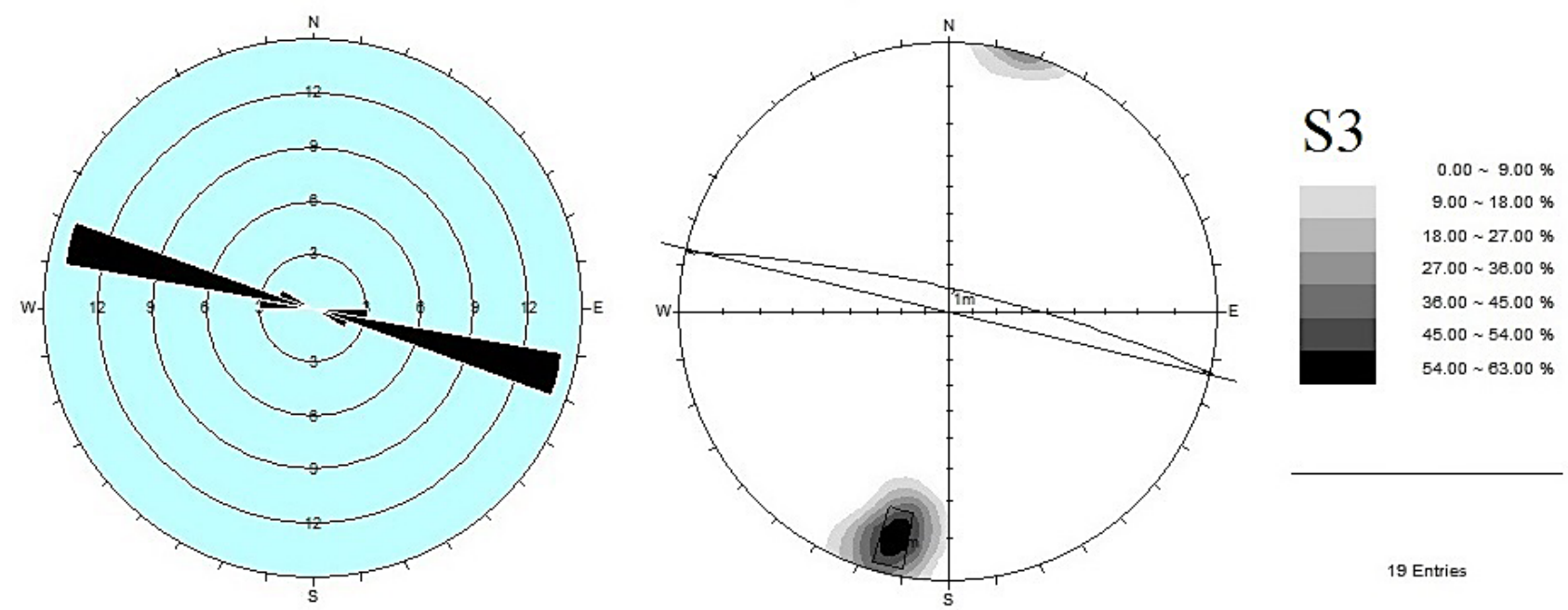

Group Inc., 2013). The number of main joint sets, spacing, aperture, dip, and dip direction were considered as input parameters. 3DEC is a three-dimensional program that assumes discontinuities as planes to determine the geometry of the rock blocks (Haghnejad et al., 2018).

All active benches were selected to study, and the joint network and rock blocks formed by the joint set were simulated by 3DED. The desired dimensions of the rock block in this quarry are $2.5 \mathrm{~m}$ in width $* 1.5 \mathrm{~m}$ in height $* 1.5 \mathrm{~m}$ in depth. Therefore in the modelling stage, cutting lines are simulated by three main joint sets perpendicular together. All blocks were simulated by considering the same excavation direction of the quarry. After the bench simulation stage, the volume and the to- 

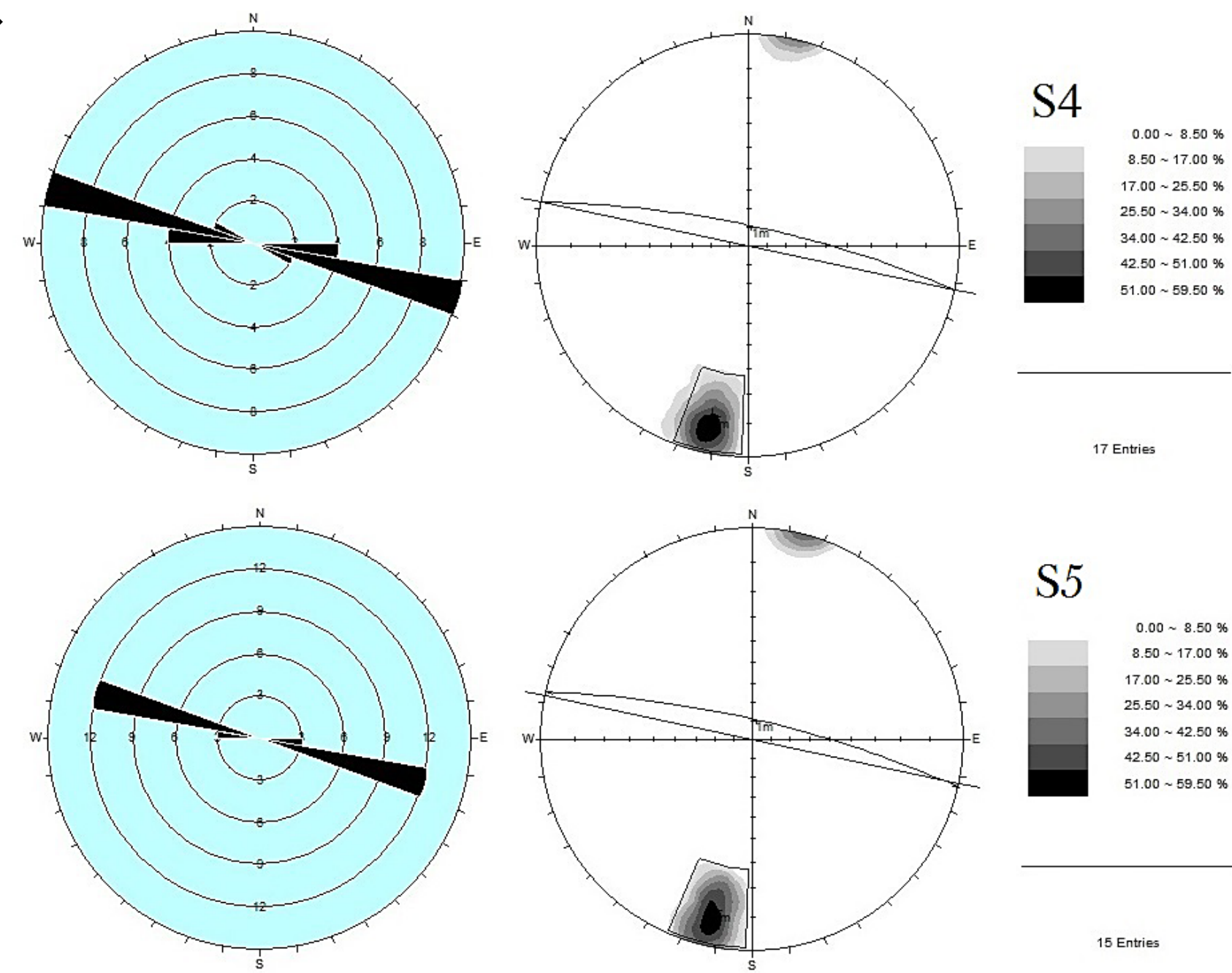

Figure 4: Stereographic projection of the discontinuities

Table 2: Properties of cutting lines

\begin{tabular}{|l|l|l|l|}
\hline Cutting line & Dip (Degree) & $\begin{array}{l}\text { Dip Direction } \\
\text { (Degree) }\end{array}$ & Spacing (m) \\
\hline L1 & 90 & 0 & 1.5 \\
\hline L2 & 90 & 90 & 2.5 \\
\hline L3 & 0 & 0 & 1.5 \\
\hline
\end{tabular}

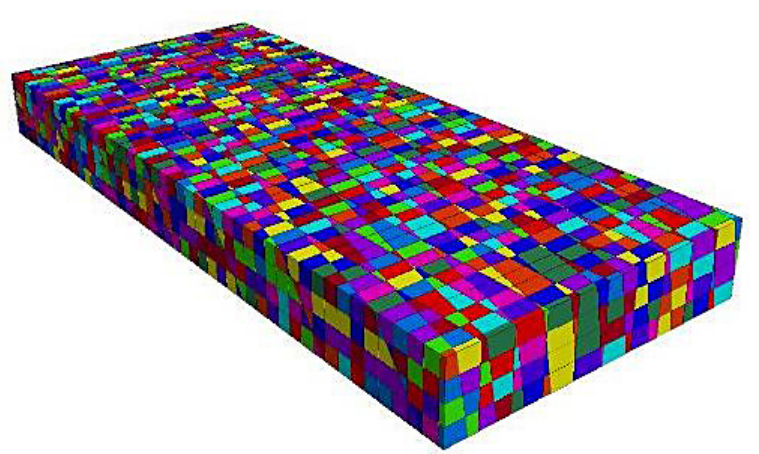

Figure 5: Bench 1-Current excavation direction

tal number of generated blocks for each active bench by considering the current discontinuity network and pri-

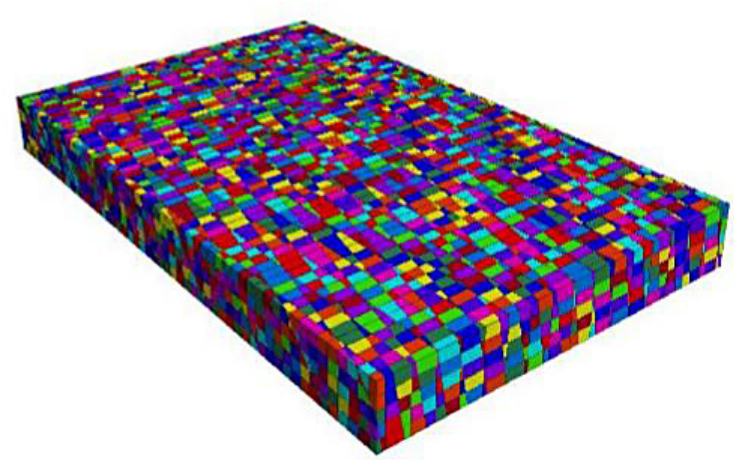

Figure 6: Bench 2-Current excavation direction

mary cutting lines direction were calculated. Table $\mathbf{2}$ indicates the cutting line information considered as three main joint sets based on the rock block's desired dimensions:

The volume of marketable dimensional stones in this quarry is $1 \mathrm{~m}^{3}$. Rock blocks with less than $1 \mathrm{~m}^{3}$ volume are considered quarry waste. The marketable volume exploitation mainly controls production. Figure 5 to Figure 11 show the result of discontinuity modelling by 


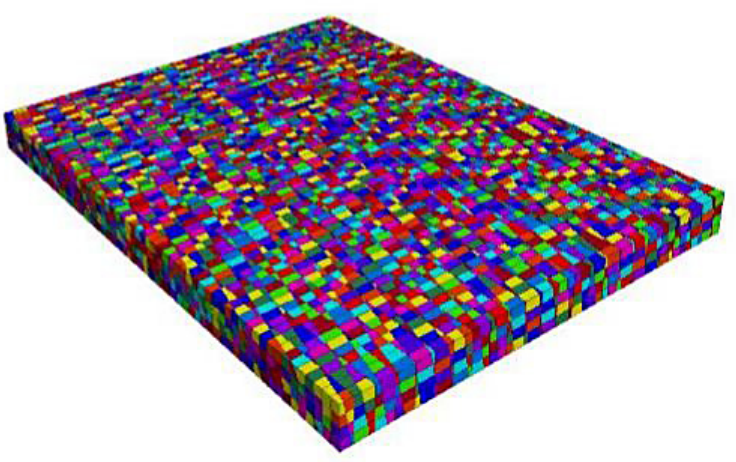

Figure 7: Bench 3-Current excavation direction

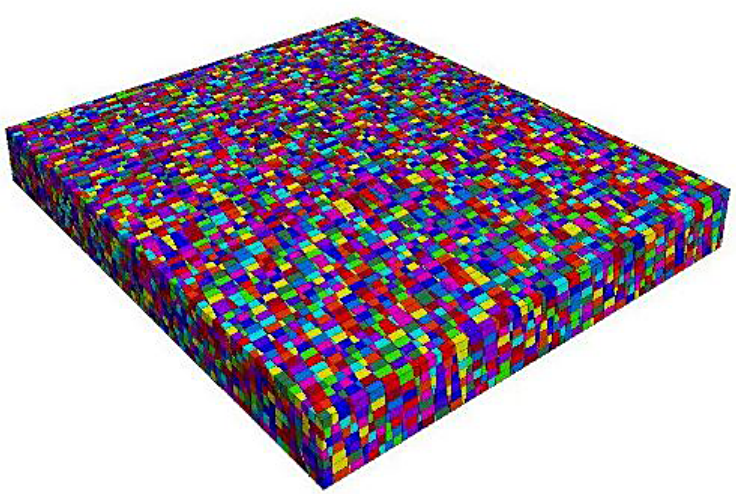

Figure 8: Bench 4-Current excavation direction

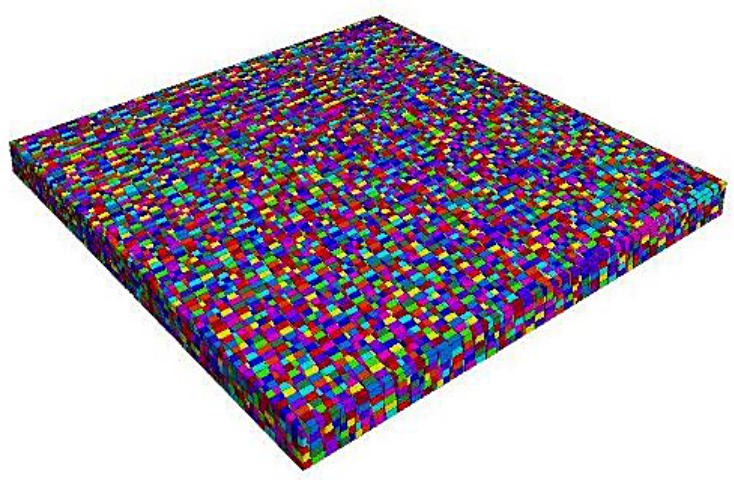

Figure 9: Bench 5-Current excavation direction

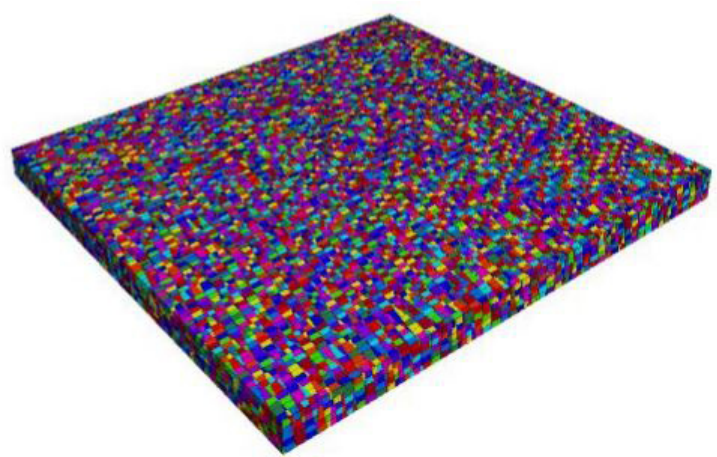

Figure 10: Bench 6-Current excavation direction

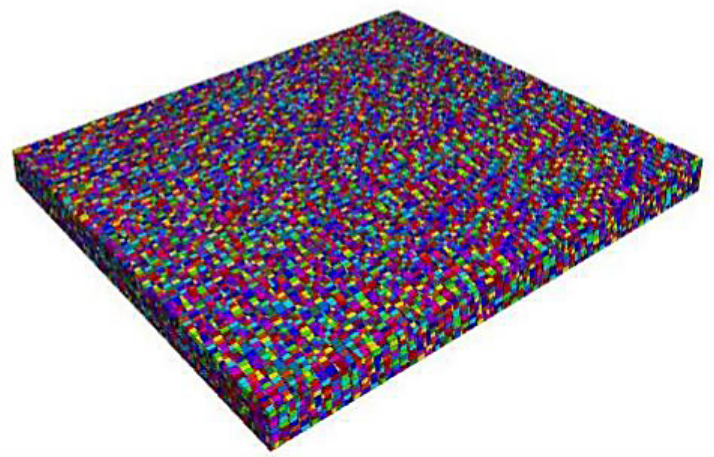

Figure 11: Bench 7-Current excavation direction

3DEC and Table 3 presents the results of $3 \mathrm{D}$ simulation for each active bench:

The marketable volume exploitation mainly controls the production rate; therefore, it is recommended to increase the marketable block's volume to improve the mining efficiency. Figure 12 presents the volume of the generated blocks and marketable blocks for each bench.

Production rate for each bench was determined and the results are presented in Table 4:

\section{Results and Discussion}

The structural features control the quarry's block size and can affect the dimension stone production technique.

Table 3: Properties of benches after modelling

\begin{tabular}{|l|l|l|l|l|l|}
\hline Bench & $\begin{array}{l}\text { Bench dimension } \\
\text { (meter) }\end{array}$ & $\begin{array}{l}\text { Number of generated } \\
\text { blocks by discontinuity } \\
\text { network }\end{array}$ & $\begin{array}{l}\text { Number of } \\
\text { marketable rock } \\
\text { blocks }\end{array}$ & $\begin{array}{l}\text { Volume of } \\
\text { generated blocks } \\
\left.\mathbf{( m}^{3}\right)\end{array}$ & $\begin{array}{l}\text { Volume of } \\
\text { marketable rock } \\
\text { blocks }\left(\mathbf{m}^{\mathbf{3}}\right)\end{array}$ \\
\hline 1 & $70 \times 30 \times 6.5$ & 4634 & 3586 & 14490.0 & 14191.9 \\
\hline 2 & $80 \times 50 \times 8$ & 11306 & 8632 & 32000.0 & 31235.2 \\
\hline 3 & $90 \times 70 \times 6.6$ & 13734 & 10606 & 41580.0 & 40693.0 \\
\hline 4 & $98.5 \times 87 \times 11.5$ & 37454 & 25394 & 98549.0 & 96401.1 \\
\hline 5 & $110.5 \times 111 \times 8$ & 33520 & 25782 & 98124.0 & 95926.3 \\
\hline 6 & $123.5 \times 137 \times 8.3$ & 46552 & 35394 & 140431.9 & 137161.4 \\
\hline 7 & $135.5 \times 161 \times 11.2$ & 50505 & 41984 & 124501.0 & 121510.32 \\
\hline
\end{tabular}




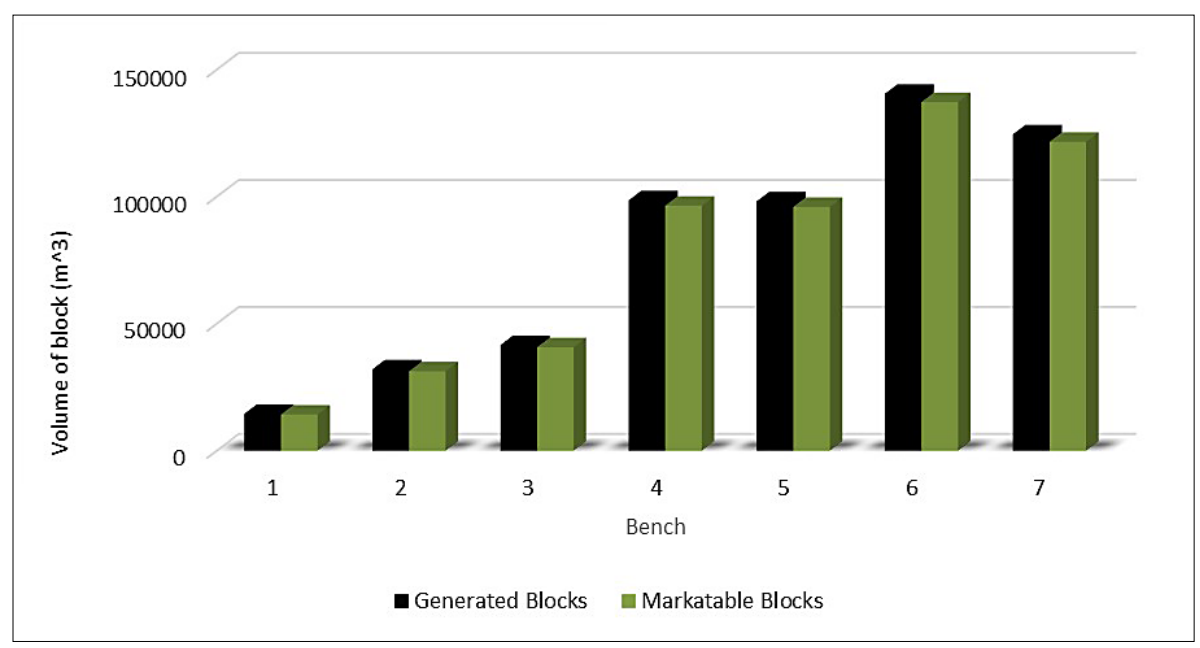

Figure 12: Volume of generated blocks and marketable blocks for each bench

Table 4: Production rate for each bench

\begin{tabular}{|l|c|c|c|c|c|c|c|}
\hline Bench & $\mathbf{1}$ & $\mathbf{2}$ & $\mathbf{3}$ & $\mathbf{4}$ & $\mathbf{5}$ & $\mathbf{6}$ & $\mathbf{7}$ \\
\hline Production rate & 97.94 & 97.61 & 97.87 & 97.82 & 97.76 & 97.67 & 97.60 \\
\hline
\end{tabular}

Table 5: Properties of benches after modelling-recommended direction

\begin{tabular}{|l|l|l|l|l|l|}
\hline Bench & $\begin{array}{l}\text { Bench dimension } \\
\text { (meter) }\end{array}$ & $\begin{array}{l}\text { Number of generated } \\
\text { blocks by discontinuity } \\
\text { network }\end{array}$ & $\begin{array}{l}\text { Number of } \\
\text { marketable rock } \\
\text { blocks }\end{array}$ & $\begin{array}{l}\text { Volume of } \\
\text { generated blocks } \\
\left(\mathbf{m}^{\mathbf{3}}\right)\end{array}$ & $\begin{array}{l}\text { Volume of } \\
\text { marketable rock } \\
\text { blocks }\left(\mathbf{m}^{\mathbf{3}}\right)\end{array}$ \\
\hline 1 & $70 \times 30 \times 6.5$ & 4512 & 3936 & 14490.0 & 14268.6 \\
\hline 2 & $80 \times 50 \times 8$ & 11306 & 9660 & 32000.0 & 31619.5 \\
\hline 3 & $90 \times 70 \times 6.6$ & 13734 & 11760 & 41580.0 & 40997.3 \\
\hline 4 & $98.5 \times 87 \times 11.5$ & 37454 & 30251 & 98549.0 & 97681.9 \\
\hline 5 & $110.5 \times 111 \times 8$ & 33520 & 28813 & 98124.0 & 97224.6 \\
\hline 6 & $123.5 \times 137 \times 8.3$ & 46552 & 38525 & 140431.9 & 139561.2 \\
\hline 7 & $135.5 \times 161 \times 11.2$ & 50505 & 40412 & 124501.0 & 124291.7 \\
\hline
\end{tabular}

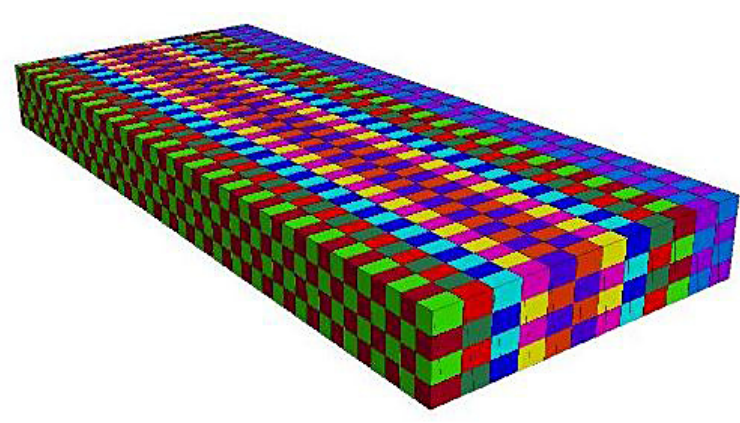

Figure 13: Bench 1-New excavation direction

In this case study, the excavation direction makes 76.56 degrees with the main joint set direction. We tried to model the blocks and bench with the new excavation direction to investigate the effect of a small variation for block size assessment. Therefore, in this stage in the simulation, we assumed that the excavation direction is equal to the main discontinuity direction.

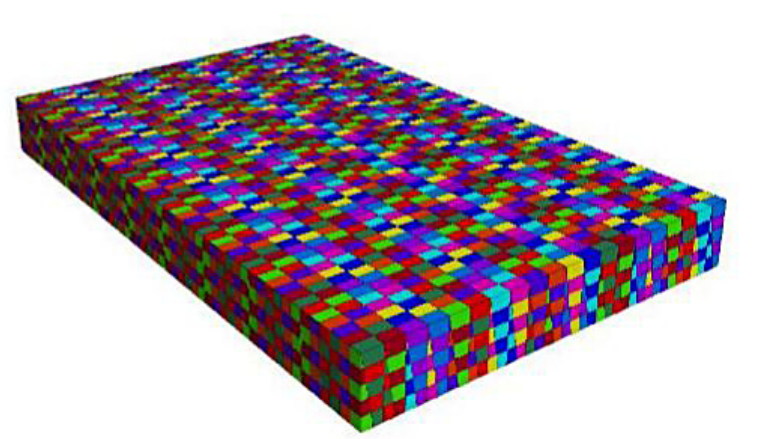

Figure 14: Bench 2-New excavation direction

The geometry of the benches modelled in 3DEC are shown in Figure 13 to Figure 19, and Table 5 presents the results of $3 \mathrm{D}$ simulation for each active bench after changing the excavation's direction:

This simulation's goal is to increase the production rate of the quarry. Figure $\mathbf{2 0}$ presents the volume of gen- 


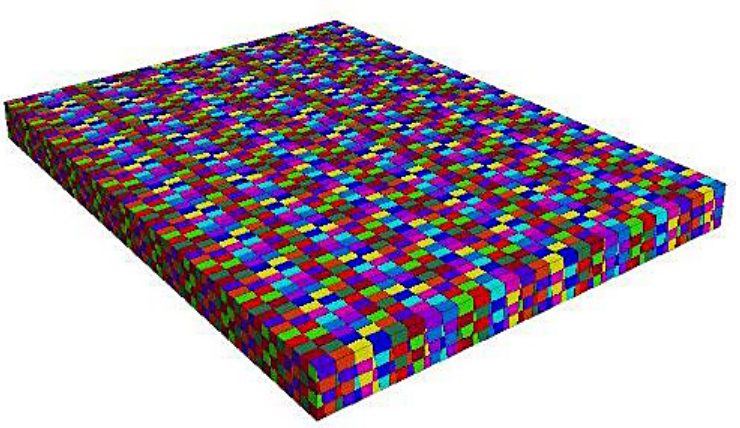

Figure 15: Bench 3-New excavation direction

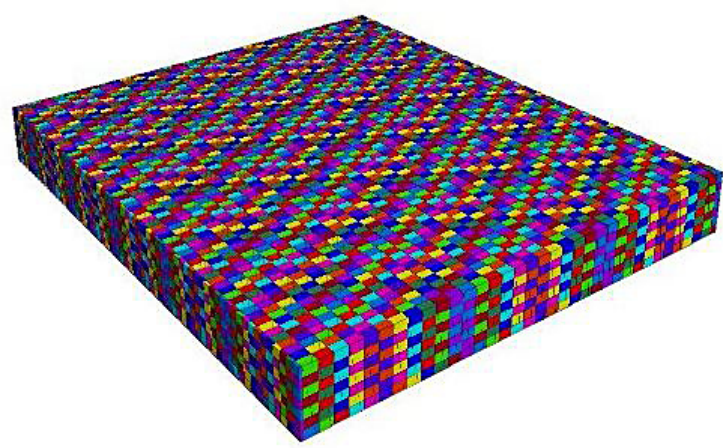

Figure 16: Bench 4-New excavation direction

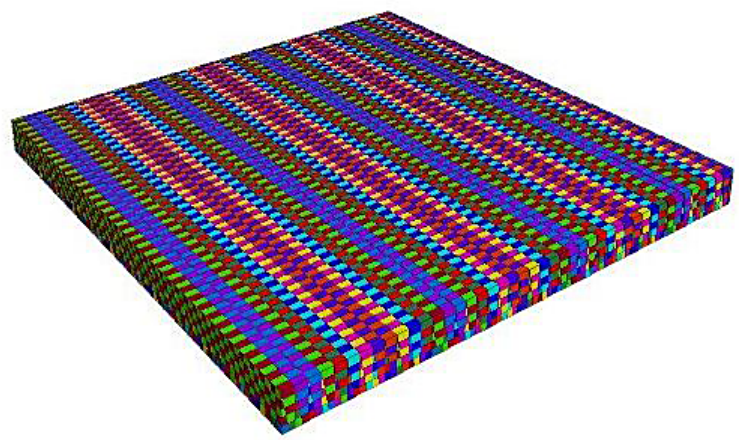

Figure 17: Bench 5-New excavation direction

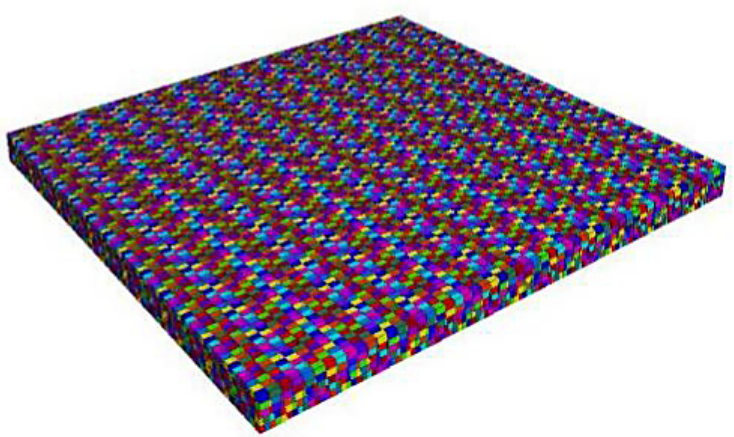

Figure 18: Bench 6-New excavation direction

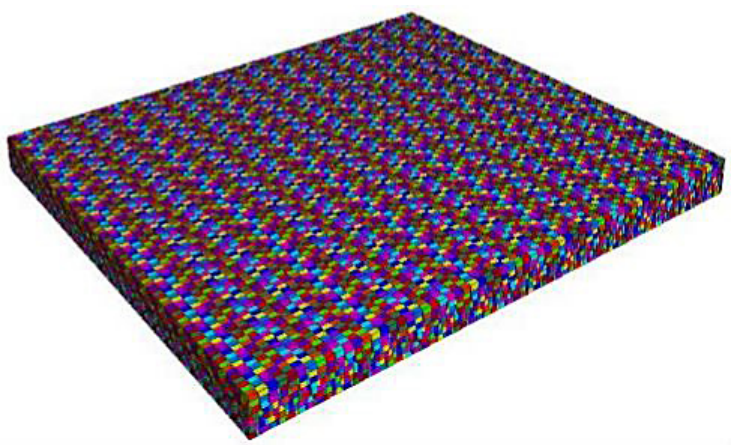

Figure 19: Bench 7-New excavation direction

erated blocks and the volume of marketable generated blocks after changing the excavation direction.

Production rate for each bench was determined and the results are presented in Table 6:

It is shown that the production rate for all benches increased by changing the direction of the bench line cut. This improvement is presented in Figure 21. It is concluded that production rate will increase by about $1.13 \%$ for all active benches by changing the extraction's direction, which has a considerable impact on mining exploitation efficiency.

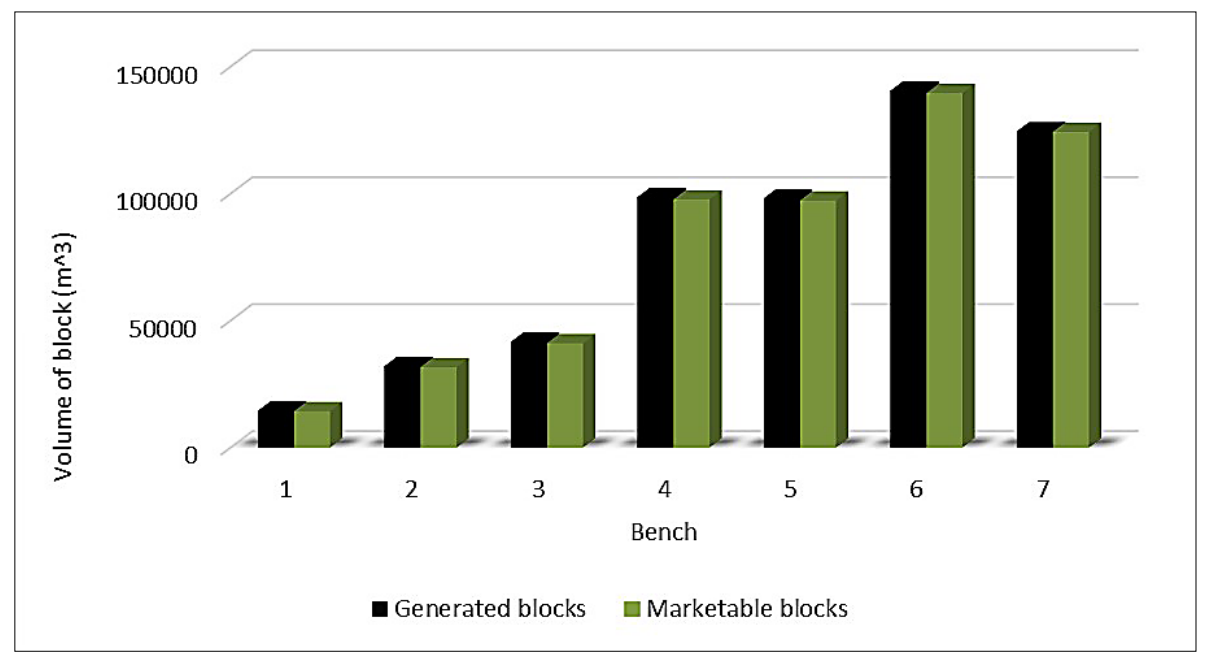

Figure 2o: Volume of generated blocks and marketable blocks for each bench-Recommended excavation direction 
Table 6: Production rate for each bench

\begin{tabular}{|l|l|l|l|l|l|l|l|}
\hline Bench & $\mathbf{1}$ & $\mathbf{2}$ & $\mathbf{3}$ & $\mathbf{4}$ & $\mathbf{5}$ & $\mathbf{6}$ & $\mathbf{7}$ \\
\hline Production rate (\%) & 98.47 & 98.81 & 98.60 & 99.12 & 99.08 & 99.38 & 99.83 \\
\hline
\end{tabular}

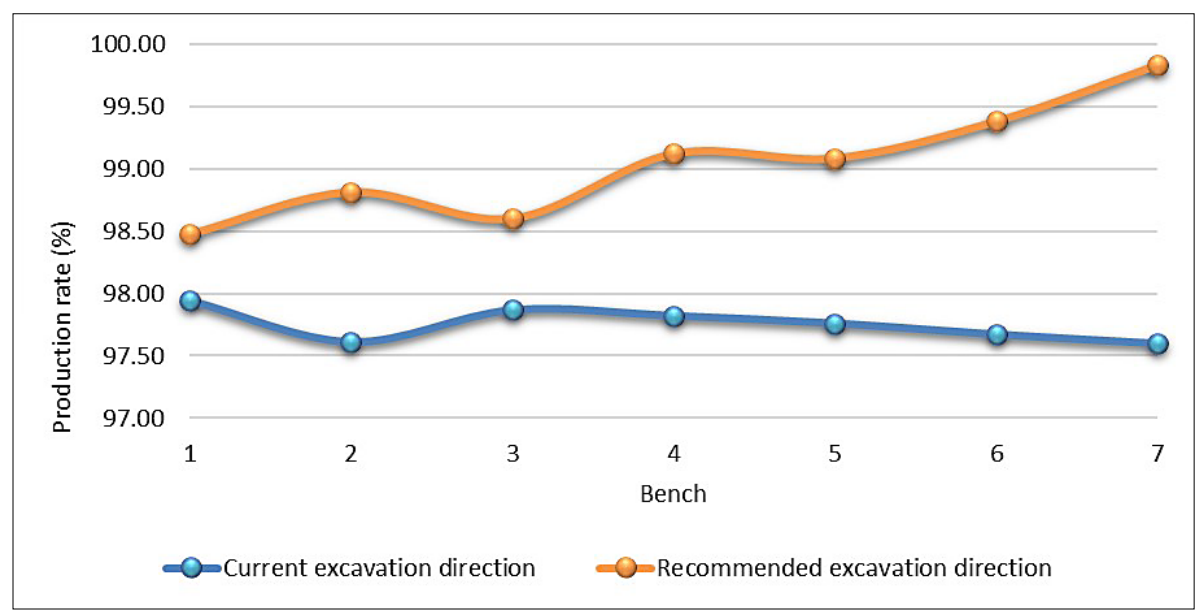

Figure 21: Comparison of production rate for two different excavation direction

\section{Conclusion}

This investigation proved that discontinuities play a critical role in the rock mass quality for the dimension stone industry. Additionally, it was discussed that discontinuities could affect the mine's production rate. Quarry management is extremely dependent on the joint pattern, and it is concluded that by changing the excavation direction of the Josheghan Mine, the production rate will increase about $1.3 \%$. The quarry industry's goal is to produce large blocks, and in the meantime, the risk for investment should be eliminated by minimizing unnecessary waste production. The results of the quarry simulation for the Josheghan Mine proved that by changing the direction of mining for active benches, the exploitation efficiency would increase considerably. The main goal of quarry mining is producing marketable materials, therefore, the authors recommend surveying various variables affecting the mine production. The authors suggest applying the window mapping technique to investigate discontinuities because using the window mapping method provides more details of the discontinuities in comparison to the scanline system.

\section{References}

Ashmole, I. and Motloung, M. (2008): Dimension stone: the latest trends in exploration and production technology. Proceedings of the International Conference on Surface Mining, 35-70.

Ataei, M., Mikaiel, R., Sereshki, F. and Ghaysari, N. (2011): Predicting the production rate of diamond wire saw using statistical analysis. Arabian Journal of Geosciences, 5(6), 1289-1295. https://doi.org/10.1007/s12517-010-0278-z
Barton, N. R. (1978): Suggested methods for the quantitative description of discontinuities in rock masses: International Society for Rock Mechanics. International Journal of Rock Mechanics and Mining Science \& Geomechanics, 15(6), 319-368.

Careddu, N. (2019): Dimension stones in the circular economy word. Resources Policy, 60, 243-245. https://doi.org/ 10.1016/j.resourpol.2019.01.012

Careddu, N., Di Capua, G. and Siotto, G. (2019): Dimension stone industry should meet fundamental values of geoethics. Resources Policy, 63, 101468. https://doi.org/10.1016/j. resourpol.2019.101468

Careddu, N., Marras, G. and Siotto, G. (2014): Recovery of sawdust resulting from marble processing plants for future uses in high value-added products. Journal of Cleaner Production, 84(1), 533-539. https://doi.org/10.1016/j.jclepro. 2013.11.062

Carvalho, J. F., Henriques, P., Fale, P. and Luis, G. (2008): Decision criteria for the exploration of ornamental-stone deposits: Application to the marbles of the Portuguese Estremoz Anticline. International Journal of Rock Mechanics and Mining Sciences, 45(8), 1306-1319. https://doi. org/10.1016/j.ijrmms.2008.01.005

Cavallo, A. (2018): Serpentinitic waste materials from the dimension stone industry: Characterization, possible reuses and critical issues. Resources Policy, 59, 17-23. https:// doi.org/10.1016/j.resourpol.2018.08.003

Cundall, P. A. (1971): A computer model for simulating progressive large scale movements in blocky system. Proceedings of the International Symposium on Rock Mechanics, II-8.

Deng, X. F., Zhu, J. B. and Chen, S. G. (2012): Some fundamental issues and verification of 3DEC in modeling wave propagation in jointed rock masses. Rock Mechanics and 
Rock Engineering, 45(5), 943-951. https://doi.org/ 10. 1007/s00603-012-0287-1

Elkarmoty, M., Bondua, S. and Bruno, R. (2020): A 3D optimization algorithm for sustainable cutting of slabs from ornamental stone blocks. Resources Policy, 65, 101533. https://doi.org/10.1016/j.resourpol.2019.101533

Franklin, J. A., Maerz, N. H. and Bennett, C. P. (1988): Rock mass characterization using photoanalysis. International Journal of Mining and Geological Engineering, 6, 97-112. https://doi.org/10.1007/BF00880801

Freire-Lista, D. M. and Fort, R. (2017): Exfoliation microcracks in building granite. Implications for anisotropy. Engineering Geology, 220, 85-93. https://doi.org/10.1016/j. enggeo.2017.01.027

Haghnejad, A., Ahangari, K., Moarefvand, P. and Goshtasbi, K. (2018): Numerical investigation of the impact of geological discontinuities on the propagation of ground vibrations. Geomechanics and Engineering, 14(6), 545-552. https://doi.org/10.12989/gae.2018.14.6.545

Hamdi Deliormanli, A., Maerz, N. H. and Otoo, J. (2014): Using terrestrial 3D laser scanning and optical methods to determine orientations of discontinuities at a granite quarry. International Journal of Rock Mechanics and Mining Sciences, 66, 41-48. https://doi.org/10.1016/j.ijrmms. 2013.12.007

Hu, Z., Xu, N., Li, B., Xu, Y., Xu, J. and Wang, K. (2020): Stability analysis of the arch crown of a large-scale underground powerhouse during excavation. Rock Mechanics and Rock Engineering, 53(6), 2935-2943. https://doi.org/ $10.1007 / \mathrm{s} 00603-020-02077-4$

Itasca Consulting Group Inc. (2013). 3DEC-3 Dimensional Distinct Element Code.

Khoshouei, M., Jalalian, M. H., and Bagherpour, R. (2020): The effect of geological properties of dimension stones on the prediction of Specific Energy (SE) during diamond wire cutting operations. Rudarsko-geološko-naftni zbornik (The Mining-Geology-Petroleum Engineering Bulletin), 35(3), 17-27. https://doi.org/10.17794/rgn.2020.3.2

Levytskyi, V., Sobolevskyi, R., and Korobiichuk, V. (2018): The optimization of technological mining parameters in a quarry for dimension stone blocks quality improvement based on photogrammetric techniques of measurement. Rudarsko-geološko-naftni zbornik (The Mining-GeologyPetroleum Engineering Bulletin), 33(2), 83-89. https://doi. org/10.17794/rgn.2018.2.8

Li, T., Du, Y., Zhu, Q., Ren, Y., Zhang, H. and Ran, J. (2021): Hydro-mechanical coupling behaviors in the failure process of pre-cracked sandstone. Geomechanics and Engineering, 24(6), 573-588. https://doi.org/10.12989/ gae.2021.24.6.573

Li, X., Chen, Z., Chen, J. and Zhu, H. (2019): Automatic characterization of rock mass discontinuities using 3D point clouds. Engineering Geology, 259, 105131. https://doi. org/10.1016/j.enggeo.2019.05.008

Luodes, H., Selonen, O. and Paakkonen, K. (2000): Evaluation of dimension stone in gneissic rocks-a case history from southern Finland. Engineering Geology, 58(2), 209223. https://doi.org/10.1016/S0013-7952(00)00059-4

Mosch, S., Nikolayew, D., Ewiak, O. and Siegesmund, S. (2011): Optimized extraction of dimension stone blocks. Environmental Earth Sciences, 63, 1911-1924. https://doi. org/10.1007/s12665-010-0825-7

Niini, H. (1986): Classification and development of bedrock resources in Finland. Bulletin of The Geological Society of Finland, 58, 335-350. https://doi.org/10.17741/BGSF/ 58.1 .022

Palmstrom, A. and Broch, E. (2006): Use and misuse of rock mass classification systems with particular reference to the Q-system. Tunneling and Underground Space Technology, 21(6), 575-593. https://doi.org/10.1016/j.tust.2005.10.005

Priest, S. D. and Hudson, J. A. (1976): Discontinuity spacings in rock. International Journal of Rock Mechanics and Mining Sciences \& Geomechanics Abstracts, 13(5), 135-148. https://doi.org/10.1016/0148-9062(76)90818-4

Rzyczniak, M., Solecki, M. L., Zeljaś, D., and Dubiel, S. J. (2021): The effect of pressure depression on the water inflow volume to wells which cover carbonate rocks in the Carpathian Foredeep basement, SE Poland. Rudarskogeološko-naftni zbornik (The Mining-Geology-Petroleum Engineering Bulletin), 36(2), 33-42. https://doi.org/10.17 794/rgn.2021.2.4

Sousa, L. M. O. (2010): Evaluation of joints in granitic outcrops for dimension stone exploitation. Quarterly Journal of Engineering Geology and Hydrogeology, 43(1), 85-94. https://doi.org/10.1144/1470-9236/08-076

Sturzenegger, M. (2010): Multi-scale characterization of rock mass discontinuities and rock slope geometry using terrestrial remote sensing techniques. Simon Fraser University, $343 \mathrm{p}$.

Wang, X., Kulatilake, P. H. S. W. and Song, W. (2012): Stability investigations around a mine tunnel through three-dimensional discontinuum and continuum stress analyses. Tunneling and Underground Space Technology, 32, 98112. https://doi.org/10.1016/j.tust.2012.06.003

Wines, D. R., and Lilly, P. A. (2002): Measurement and analysis of rock mass discontinuity spacing and frequency in part of the Fimiston Open Pit operation in Kalgoorlie, Western Australia: a case study. International Journal of Rock Mechanics and Mining Sciences, 39(5), 589-602. https://doi.org/10.1016/S1365-1609(02)00003-5

Yarahmadi, R., Bagherpour, R., Sousa, L. M. O., and Taherian, S.-G. (2015): How to determine the appropriate methods to identify the geometry of in situ rock blocks in dimension stones. Environmental Earth Sciences, 74(9), 6779-6790. https://doi.org/10.1007/s12665-015-4672-4

Yarahmadi, R., Bagherpour, R., Taherian, S.-G. and Sousa, L. M. O. (2018): Discontinuity modelling and rock block geometry identification to optimize production in dimension stone quarries. Engineering Geology, 232, 22-33. https:// doi.org/10.1016/j.enggeo.2017.11.006

Zhang, L., Elsevier Geo-Engineering Book Series, and Elsevier (Eds.). (2006): 4 Rock discontinuities" (pp. 53-97). https://doi.org/10.1016/S1571-9960(06)80007-8 


\section{SAŽETAK}

\section{Maksimiziranje efikasnosti rudarenja u kamenolomu, prikaz studije slučaja}

Danas industrija arhitektonsko-građevnoga kamena zauzima važno mjesto u svjetskoj ekonomiji. Time raste i važnost kamenoloma. Postoje također i rizici povezani s takvim aktivnostima, posebice financijski. Nazočnost pukotina u stijenskoj masi može biti glavni rizik među njima, jer one ruše kvalitetu kamena, a time utječu na iskoristivost kamenoloma. Stoga je vrlo važno istražiti pukotine, stijenske blokove, njihovu geometriju i dimenzije prije otkopavanja, kako bi se podigla iskoristivost i smanjila količina jalovine. Ovdje su izučene pukotine u kamenolomu vapnenca u Josheghanu, Iran. Izračunana je odgovarajuća geometrija stijenskih blokova važna za eksploataciju. Metodom Scanline predviđene su pukotine na sedam radilišta, a paketom 3DEC za cijeli kamenolom. Izračunano je kako se smjer otkopavanja treba projicirati s otklonom od 13,14 stupnjeva u odnosu na glavni smjer pružanja pukotina. Dokazano je kako se promjenom smjera rudarenja povećava i udjel jalovine. No, rudarenjem pod navedenim kutom povećat će se pridobivanje za 1,13 \% u usporedbi s trenutačnim. Na radilištu broj sedam zabilježena je minimalna proizvodnja od 97,6o, a primjenom ovih rezultata očekuje se dosizanje vrijednosti od 99,83. Na taj način moguće je znatno povećati proizvodnju i iskoristivost.

\section{Ključne riječi:}

arhitektonsko-građevni kamen, financijski rizik, mreža pukotina, stupanj iskoristivosti, geometrija stijenskih blokova

\section{Author's contribution}

Arezou Rasti (Mining and Geotechnical Engineer) contributed to idea development and the design of the study, participated in the conceptualization, methodology, data collection and formal analysis, visualization, supervision, validation and writing the manuscript. Nader Ebrahimi (Mining Engineer) contributed to designing the study, methodology, data collection and performed the test, performed the field work, data analysis and visualization, and writing the manuscript. Morteza Tabaei (Associate Professor) contributed to idea development and the design of the study, methodology, writing and reviewing the manuscript. Hamid Ranjkesh Adarmanabadi (Master Student) contributed to the design of the study, data analysis and visualization, writing and reviewing the manuscript. 